\title{
THE STRUCTURE OF ALLOYS OF BORON-RICH CORNER OF Fe-B-C PHASE DIAGRAM
}

\author{
O.V. Sukhova \\ Oles Honchar Dnipro National University, Dnipro, Ukraine \\ e-mail: sukhovaya@ukr.net
}

The structure and microdurometric characteristics of the $\mathrm{Fe}-\mathrm{B}-\mathrm{C}$ alloys in the range of high concentration of boron $(>16.0 \mathrm{wt}$. \% $\mathrm{B})$ and low concentration of carbon $(\leq 0.1 \mathrm{wt} . \% \mathrm{C})$ were investigated in this work. The methods of quantitative metallographic, X-ray, differential thermal, fluorescent spectral and microdurometric analyses were applied. Carbon was established to dissolve completely in phase constituents of the investigated alloys, forming solid solutions based on iron borides $\mathrm{FeB}, \mathrm{FeB}_{2}, \mathrm{FeB}_{\sim 4}$ or $\mathrm{FeB}_{\sim 19}$. It was suggested the existence of one eutectic transformation between borides $\mathrm{FeB}_{2}$ and $\mathrm{FeB}_{\sim 4}$ as well as two peritectic transformations between borides $\mathrm{FeB}$ and $\mathrm{FeB}_{2}$ or $\mathrm{FeB}_{\sim 4}$ and $\mathrm{FeB}_{\sim 19}$ correspondingly in the studied concentration range. The formation of boride $\mathrm{FeB}_{\sim 4}$ was explained by its stabilization in the presence of carbon in the alloys. After annealing in vacuum at $900{ }^{\circ} \mathrm{C}$ for 10 hours with following quenching, the structure became coarser, but no traces of phase decomposition were revealed in the most alloys. Microhardness of the phases observed in the structure of the investigated alloys increased in the following sequence: $\mathrm{FeB} \rightarrow \mathrm{FeB}_{2} \rightarrow \mathrm{FeB} \sim 4 \rightarrow \mathrm{FeB} \sim 19$.

Keywords: phase diagram, structure, iron borides, phase transformations, microdurometric characteristics.

Received 14.06.2020; Received in revised form 02.08.2020; Accepted 04.09.2020

\section{Introduction}

Equilibrium Fe-B diagrams are based on the studies by Hannesen, Chizevsky, Gerdt, Wever, and Müller [1] The experimental data are mostly similar but differ in the boron solubility in solid iron. Moreover, Hannesen discovered that $\mathrm{Fe}-\mathrm{B}$ system had a stable $\mathrm{Fe}_{5} \mathrm{~B}_{2}$ boride, but Chizhevsky and Gerdt introduced the $\mathrm{Fe}_{2} \mathrm{~B}$ boride. Wever and Müller confirmed the formation of the $\mathrm{Fe}_{2} \mathrm{~B}$ boride and explained the above discrepancies by contamination of the studied alloys by carbon, aluminum, and silicon. In alloys with boron content higher than 8.83 wt. \%, they discovered the congruently-melting FeB compound (16.23 wt. \% B) that existed in two polymorphic modifications $(\alpha-\mathrm{FeB}$ and $\beta-\mathrm{FeB})$. Later Khan, Kneller, and Sostarich announced the existence of $\mathrm{Fe}_{3} \mathrm{~B}$ that had two stable modifications within the temperature range of $1150-1250{ }^{\circ} \mathrm{C}[1]$.

In studying $\mathrm{Fe}-\mathrm{B}$ system, a question arose, however, whether only three borides were formed since the most of transition metals had more than three borides. These speculations allowed Voroshnin et. al. [2] to assume that $\mathrm{Fe}-\mathrm{B}$ system produces $\mathrm{FeB}_{2}$ diboride that melted congruently at the concentration of $27.9 \mathrm{wt}$ \% $\mathrm{B}$. The authors showed that alloys containing more than 16 wt. $\% \mathrm{~B}$ might generate $\mathrm{FeB}-\mathrm{Fe}_{2} \mathrm{~B}$ eutectics. Moreover, the authors suggested that the diagram might also contain some third eutectic transformation at high boron concentrations between $\mathrm{FeB}_{2}$ and pure boron. Then Marder described $\mathrm{FeB} \sim 19$ phase with variable boron content but did not confirmed the existence of $\mathrm{FeB}_{2}$ diboride in boron-rich region of $\mathrm{Fe}-\mathrm{B}$ phase diagram [3]. Tylkina and Bochvar suggested eutectic reaction between $\mathrm{FeB}$ and $\beta-\mathrm{B}$ [4]. They determined the solubility of iron in boron (about $2 \%$ ) that was limited by a content of $\mathrm{FeB}_{49}$. Krukovich et al. proposed equilibrium diagram of $\mathrm{Fe}-\mathrm{B}$ system that considered the existence of five experimentally defined iron borides, namely $\mathrm{Fe}_{3} \mathrm{~B}, \mathrm{Fe}_{2} \mathrm{~B}$, $\mathrm{FeB}, \mathrm{FeB}_{2}$, and $\mathrm{FeB} \sim 19$. This diagram is based on Marder's diagram, with two missing borides $\mathrm{Fe}_{3} \mathrm{~B}$ and $\mathrm{FeB}_{2}$ as well as eutectic reaction $\mathrm{L} \rightarrow \mathrm{FeB}_{2}+\mathrm{FeB} \sim 19$ (at 34 wt. \% B) and peritectic reaction $\mathrm{L}+\beta-\mathrm{B} \rightarrow \mathrm{FeB} \sim 19$ (at $78.6 \mathrm{wt} . \% \mathrm{~B}$ ) added [1]. It was shown that the solubility of iron in $\mathrm{FeB} \sim 19$ phase might decrease from 29 to 21.4 wt. \% with temperature lowering.

Thus, the structure of iron alloys containing more than $16.0 \mathrm{wt} . \% \mathrm{~B}$ is a point at issue. 
Besides, it should be taken into consideration that iron is very reactive with carbon. Carbon may easily absorb from the air and, therefore, it should be considered as natural addition to $\mathrm{Fe}-\mathrm{B}$ alloys. Nevertheless, the investigations of the $\mathrm{Fe}-\mathrm{B}-\mathrm{C}$ alloys are limited by a content of 18 wt. \% B [5-11]. In the same time Fe-B-C alloys attract lots of interest because they exhibit high hardness, wear resistance, oxidation and heat resistance [12-14]. In this connection it seems interesting to investigate the structural composition and the mechanical properties of the alloys in the boron-rich corner of $\mathrm{Fe}-\mathrm{B}-\mathrm{C}$ diagram.

\section{Experimental procedure}

The Fe-B-C alloys containing 16.5-50.0\% B, 0.01-0.1\% C, Fe - the balance (in wt. \%) were prepared of high purity (99.93-99.99\%) components and melted in alumina crucibles using arc vacuum furnace. The samples were cooled up to room temperature together with furnace and annealed at $900^{\circ} \mathrm{C}$ for 10 hours in vacuum. The average chemical composition of the alloys was studied by fluorescent spectroscopy method using Sprut CEФ-01-M device. The alloys were examined by light-optical microscope Neophot. Quantitative metallography was carried out with structural analyzer Epiquant. X-ray diffraction (XRD) analysis was done to identify the existing phases in produced samples on X-ray diffractometer ДРОН-УM-1 with $\mathrm{CuK}_{\alpha}$ source. The phase transformations were investigated by means of differential thermal analysis. Cooling curves were recorded for each sample at a cooling rate of $5 \mathrm{~K} / \mathrm{min}$. The Vickers microhardness was measured from at least 10 different indentations, and microbrittleness was evaluated from the crack length at the corners of the Vickers microindentation using ПMT-3 device.

\section{Results and discussion}

The $\mathrm{Fe}-\mathrm{B}-\mathrm{C}$ alloys in the range of $16.5-17.5$ wt. \% B exhibit two-phase structure consisting of $\mathrm{FeB}$ and $\mathrm{FeB}_{2}$ borides alloyed with carbon (Fig. 1). A peritectic reaction $\mathrm{L}+\mathrm{FeB} \rightarrow \mathrm{FeB}_{2}$ has been suggested as a formation mechanism of the $\mathrm{FeB}_{2}$ phase. The $\mathrm{FeB}$ monoboride grows in the form of rounded dendrite with branches developed from the peaks of hexagons, and the $\mathrm{FeB}_{2}$ diboride grows as anisotropic prism (Table 1). The microhardness and microbrittleness of $\mathrm{FeB}_{2}$ phase are higher than those of $\mathrm{FeB}$.

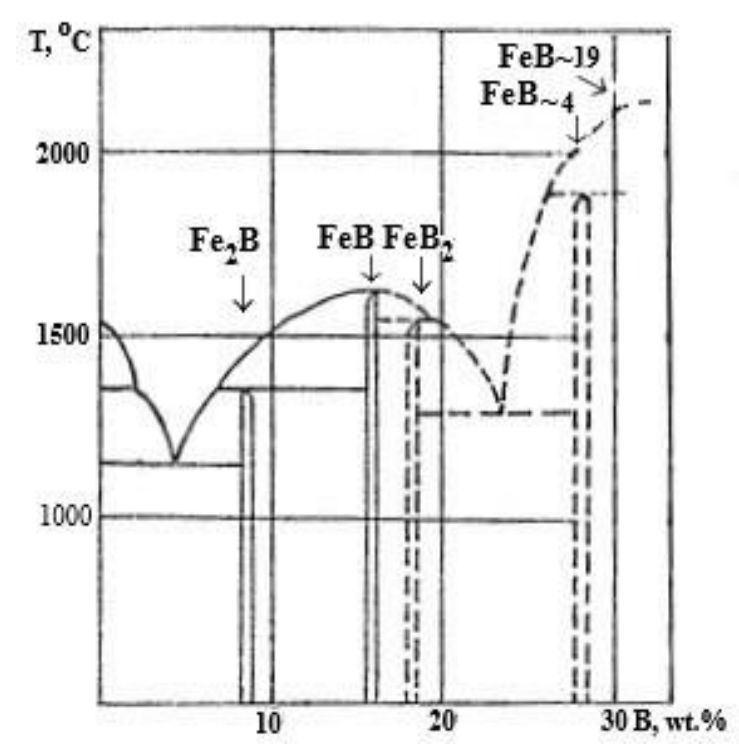

Fig. 1. Isoconcentration section (at 0.1 wt. \% C) of Fe-B-C phase diagram. 
The properties of iron borides in $\mathrm{Fe}-\mathrm{B}-\mathrm{C}$ alloys

\begin{tabular}{|c|c|c|c|}
\hline Boride & Growth form & Microhardness, $\mathrm{GPa}$ & Microbrittleness, units \\
\hline $\mathrm{FeB}$ & Dendrite & $19.29 \pm 0.4$ & $2.5 \pm 0.3$ \\
\hline $\mathrm{FeB}_{2}$ & Prism & $21.15 \pm 0.6$ & $6.0 \pm 0.2$ \\
\hline $\mathrm{FeB}_{\sim 4}$ & Plate & $27.76 \pm 0.5$ & $7.6 \pm 0.6$ \\
\hline $\mathrm{FeB}_{\sim 19}$ & Prism & $53.04 \pm 0.8$ & $1.2 \pm 0.8$ \\
\hline
\end{tabular}

As boron content further increases up to $22.7 \mathrm{wt}$ \%, primary crystals of unknown phase embedded in the eutectic are formed. The X-ray diffraction analysis reveals the presence of lines that are not attributable to the known borides. This phase may be identified as $\mathrm{FeB}_{\sim 4}$ boride that has hexagonal crystal lattice belonging to structural type $\mathrm{MoB}_{4}$ (Table 2). The growth form of $\mathrm{FeB}_{\sim 4}$ boride is found to be a plate. Sometimes, plates nucleate one on another which makes it difficult to distinguish their form and dimensions. This phase has high microhardness and microbrittleness (Table 1).

Table 2

XRD results for $\mathrm{FeB}_{\sim 4}$ phase

\begin{tabular}{|c|c|c|c|c|}
\hline \multicolumn{2}{|c|}{$\mathrm{d}_{\mathrm{hkl}}, \AA$} & \multicolumn{2}{|c|}{$\mathrm{I}, \%$} & \multirow{2}{*}{$\mathrm{hkl}$} \\
\cline { 1 - 3 } calculated* $^{*}$ & experimental & calculated* & experimental & \\
\hline 4.52 & 4.64 & 10 & 5 & 100 \\
\hline 3.68 & 3.74 & 100 & 100 & 101 \\
\hline 3.18 & 3.18 & 60 & 25 & 002 \\
\hline 2.61 & 2.60 & 80 & 30 & 101 \\
\hline 2.02 & 2.01 & 100 & 80 & 201 \\
\hline 1.59 & 1.60 & 30 & 10 & 112 \\
\hline 1.55 & 1.56 & 30 & 15 & 004 \\
\hline 1.51 & 1.50 & 60 & 20 & 203 \\
\hline 1.33 & 1.36 & 30 & 10 & 300 \\
\hline 1.21 & 1.20 & 40 & 30 & 213 \\
\hline
\end{tabular}

* - the values are determined from the XRD pattern of $\mathrm{MoB}_{4}$ boride.

Considering the existence of $\mathrm{FeB}_{\sim 4}$ boride, it may be concluded that the eutectic observed in the structure of the alloys containing 18-25.5 wt. \% B is formed by the reaction $\mathrm{L} \rightarrow \mathrm{FeB}_{2}+\mathrm{FeB}_{\sim 4}$. It has irregular morphology and microhardness of 21.823.5 GPa.

As boron content exceeds 25.5 wt. \%, primary crystals of $\mathrm{FeB}_{\sim 19}$ boride are revealed in the structure. They are arranged in the background of $\mathrm{FeB}_{\sim 4}$ crystals formed via peritectic reaction $\mathrm{L}+\mathrm{FeB}_{\sim 19} \rightarrow \mathrm{FeB}_{\sim 4}$ (Fig. 1). $\mathrm{XRD}$ results confirm that $\mathrm{FeB}_{\sim 19}$ phase is a solid solution of iron in $\beta$-rhombohedral boron $[2,3]$. It has a trigonal crystal lattice and belongs to $\mathrm{R} 3 \mathrm{~m}$ space group. The parameters of elementary cell of $\mathrm{FeB}_{\sim 19}$ boride are as follows: $a=10.2470 \AA, \alpha=70.5^{\circ}$. Metallographic analysis reveals prismatic zonal structure of this boride, the edge branches of prisms control crystallization process. The $\mathrm{FeB}_{\sim 19}$ boride exhibits the highest microhardness and lowest microbrittleness (Table 1).

After annealing in vacuum at $900{ }^{\circ} \mathrm{C}$ for 10 hours with following quenching, the coarsening of the structural constituents is observed due to the boron redistribution, but no traces of phase decomposition are revealed in the most alloys. An only exception is the alloy containing $18 \mathrm{wt} \% \% \mathrm{~B}$ in which $\mathrm{FeB}_{2}$ precipitates inside $\mathrm{FeB}$ crystals increasing the microhardness of FeB monoboride up to $20.5 \mathrm{GPa}$. 


\section{Conclusions}

The metallographic and thermo-analytic investigation of ternary $\mathrm{Fe}-\mathrm{B}-\mathrm{C}$ alloys containing 16.5-50.0 wt. \% B, 0.01-0.1 wt. \% C indicates that borides previously reported as $\mathrm{FeB}, \mathrm{FeB}_{2}$, and $\mathrm{FeB}_{\sim 19}$ are formed in the structure. Carbon added to $\mathrm{Fe}-\mathrm{B}$ alloys completely dissolves in these phase constituents. Differences against earlier reports are found in the suggested existence of peritectic reactions $\mathrm{L}+\mathrm{FeB} \rightarrow \mathrm{FeB}_{2}$, $\mathrm{L}+\mathrm{FeB}_{\sim 19} \rightarrow \mathrm{FeB}_{\sim 4}$ and eutectic reaction $\mathrm{L} \rightarrow \mathrm{FeB}_{2}+\mathrm{FeB}_{\sim 4}$. The phase identified as $\mathrm{FeB}_{\sim 4}$ is most likely stabilized by carbon.

\section{References}

1. Krukovich, M.G. Plasticity of boronized layers / M.G. Krukovich, B. Prusakov, I. Sizov. - Switzerland: Springer International Publishing, 2016. - 364 p.

2. Voroshnin, L.G. Structure of Fe-B system alloys / L.G. Voroshnin, L.S. Lyakhovich, G.G. Panich, G.F. Protasevich // Metallovedeniye i termicheskaya obrabotka metallov. - 1970. - No. 9. - P. $14-17$.

3. Marder, A.R. B-Fe (Boron-Iron) / A.R. Marder // Metal Handbook. Metallography, Structures and Phase Diagrams. - 1973 - v. 8 - P. 270 - 347.

4. Lyakishev, N.P. The equilibrium diagrams of binary metal systems / N.P. Lyakishev. - Moscow: Mashinostroyenie, 1996. - Vol. 1. - 992 p.

5. Sukhova, O.V. The effect of carbon content and cooling rate on the structure of boron-rich Fe-B-C alloys / O.V. Sukhova // Physics and Chemistry of Solid State. 2020. - Vol. 21, No. 2. - P. 355 - 360.

6. Spiridonova, I.M. Structure and deformation peculiarities of $\mathrm{Fe}(\mathrm{B}, \mathrm{C})$ crystals / I.M. Spiridonova, E.V. Sukhovaya, V.P. Balakin // Metallurgiya. - 1996. - Vol. 35, No. 2. - P. $65-68$.

7. Huang, Z.F. Microstructure and properties of Fe-B-C cast wear-resistant alloy / Z.F. Huang, J.D. Xing, S.Q. Ma, Y.M. Gao, M. Zheng, L.Q. Sun // Key Engineering Materials. - 2017. - Vol. 732. - P. $59-68$.

8. Ren, X. Effect of boron concentration on microstructures and properties of $\mathrm{Fe}-\mathrm{B}-$ C alloy steel / X. Ren, H. Fu, J. Xing, Y. Yang, S. Tang // Journal of Materials Research. - 2017. - Vol. 32, No. 16. - P. $304-314$.

9. Sang, P. Effect of boron concentration on solidification structure and hardness of $\mathrm{Fe}-\mathrm{B}-\mathrm{C}$ wear-resistant alloy/ P. Sang, H. Fu, Y. Qu, C. Wang, Y. Lei // Materialwissenschaft Und Werkstofftechnik. - 2015. - Vol. 46, No. 9. - P. 962 - 969.

10. Homolova, V. Experimental study of phase composition of Fe-(30-60)B-C alloys and boron-rich corner of Fe-B-C phase diagram / V. Homolova, L. Ciripova // Journal of Phase Equilibria and Diffusion. - 2015. - Vol. 36, No. 6. - P. 599 - 605.

11. Sudo, A. Fundamental experiments on phase stabilities of $\mathrm{Fe}-\mathrm{B}-\mathrm{C}$ ternary systems / A. Sudo, T. Nishi, N. Shirasu, M. Takano, M. Kurata // Journal of Nuclear Science and Technology. - 2015. - Vol. 52, No. 10. - P. $1308-1312$.

12. Spiridonova, I.M. Stabilnost kompozitsionnykh materialov / I.M. Spiridonova, A.D. Panasyuk, Ye.V. Sukhovaya, A.P. Umanskiy. - Dnipropetrovsk: Svidler, 2011. - 244 p.

13. Sukhova, O.V. Microstructure and properties of $\mathrm{Fe}-\mathrm{B}-\mathrm{C} / \mathrm{W}-\mathrm{C}$ interfaces in metal matrix composites / O.V. Sukhova // Visnyk DU. Fizyka. Radioeletronika. -2002. Vol. 9. - P. 15 - 18.

14. Sukhova, O.V. Influence of mechanisms of structure formation of interfaces in composites on their properties / O.V. Sukhova // Metallofizika i Noveishie Tekhnologii. 2009. - Vol. 31, No. 7. - P. 1001 - 1012. 